\title{
IbM KELOMPOK TANI AREN DI KECAMATAN RATAHAN: TEKNOLOGI PENGOLAHAN KECAP BERBAHAN BAKU GULA AREN
}

\author{
Emma Mauren Moko \& Livana Dethris Rawung \\ Program Studi Biologi, Fakultas Matematika dan Ilmu Pengetahuan Alam, \\ Universitas Negeri Manado (UNIMA) \\ emmamoko@unima.ac.id
}

\begin{abstract}
Abstrak
Kecamatan Ratahan merupakan salah satu Kecamatan di Kabupaten Minahasa Tenggara, yang berjarak sekitar $80 \mathrm{~km}$ dari Ibukota Propinsi Sulawesi Utara. Kondisi geografis sebagian besar wilayah Kabupaten Minahasa Tenggara adalah berlereng-lereng dan banyak ditumbuhi pohon aren, sehingga kehidupan ekonomi sebagian besar masyarakat di Kabupaten Minahasa Tenggara khususnya di Kecamatan Ratahan merupakan petani aren yang mengolah nira aren menjadi gula aren dan 'cap tikus' (cairan berkadar alkohol rata-rata 40 persen yang dihasilkan melalui penyulingan atau destilasi nira aren). Keterbatasan pengetahuan dan teknologi dari para petani aren serta nilai ekonomis cap tikus yang lebih tinggi menyebabkan petani aren lebih memilih mengolah nira aren menjadi cap tikus. Tujuan dari kegiatan IbM bagi para petani aren di Kecamatan Ratahan Kabupaten Minahasa Tenggara adalah memberikan alih teknologi berupa pelatihan pengolahan kecap manis berbahan baku gula aren. Metode yang digunakan adalah berupa kegiatan kaji tindak, kegiatan dilakukan dengan memberikan contoh secara langsung penerapan teknologi fermentasi kedelai sebagai bahan baku pembuatan kecap, hingga pemberian contoh dalam proses pengolahan kecap sehingga para petani bisa memahami metode dan proses-proses pengolahan kecap berbahan baku nira aren. Kegiatan Pengabdian bagi petani aren di Desa Tousuraya, Kecamatan Ratahan Timur memberikan manfaat yaitu perolehan informasi mengenai hilirisasi aren menjadi berbagai olahan selain gula aren dan cap tikus yaitu pengolahan kecap berbahan baku gula aren.
\end{abstract}

Kata Kunci: Kedelai, fermentasi, gula aren, kecap.

\section{PENDAHULUAN}

\section{Analisis Situasi}

Kabupaten Minahasa Tenggara adalah salah satu Kabupaten di antara 11 Kabupaten dan 4 Kota yang ada di Propinsi Sulawesi Utara. Kabupaten ini terletak diujung utara pulau Sulawesi. Ibukota Kabupaten Minahasa Tenggara adalah Ratahan, berjarak sekitar $80 \mathrm{~km}$ dari Manado, ibukota Sulawesi Utara. Kabupaten Minahasa Tenggara secara administratif telah ditetapkan dengan UU No. 9 tahun 2007. Kabupaten ini merupakan hasil pemekaran dari kabupaten induknya yaitu
Kabupaten Minahasa Selatan. Kabupaten Minahasa Tenggara dengan luas wilayah 730,62 $\mathrm{km}^{2}$ atau $73.062 \mathrm{Ha}$, yang secara administratif terbagi menjadi 12 kecamatan yaitu Kecamatan Belang, Pasan, Pusomaen, Ratahan, Ratahan Timur, Ratatotok, Silian Raya, Tombatu, Tombatu Timur, Tombatu Utara, Toulaan, dan Toulaan Selatan.

Wilayah Kabupaten Minahasa Tenggara berbatasan dengan 3 Kabupaten yang berbeda yaitu sebelah utara berbatasan dengan Kecamatan Amurang Timur, Kabupaten Minahasa Selatan, sebelah timur berbatasan dengan Kecamatan Langowan 
Kabupaten Minahasa, sebelah selatan berbatasan dengan Kecamatan Kotabunan Kabupaten Bolaang Mongondow, sedangkan sebelah barat berbatasan dengan Kecamatan Ranoyapo dan Kecamatan Kumelembuai Kabupaten Minahasa Selatan.

Keadaan geografis sebagian besar wilayah Kabupaten Minahasa Tenggara adalah bergunung-gunung dan berbukitbukit yang membentang dari utara sampai ke selatan. Diantaranya terdapat beberapa gunung berapi yang masih aktif hingga sekarang, salah satu gunung yang masih aktif tersebut adalah gunung api Soputan dengan tinggi $1.780 \mathrm{~m}$ yang terletak di antara perbatasan Kabupaten Minahasa Tenggara dan Minahasa Selatan serta Kabupaten Minahasa.

Wilayah Minahasa Tenggara sebagian besar berupa lereng. Lereng wilayah Minahasa Tenggara sebagian besar adalah antara 15 - 25\% yakni sebanyak 35\% dari luas wilayah Kabupaten Minahasa Tenggara yang meliputi hampir di seluruh Kecamatan yang ada di Minahasa Tenggara, juga lereng antara 25 - 40\% yakni sebanyak 31\%, untuk lereng antara $0-2 \%$ yang relatif datar hanya terdapat di sepanjang pantai selatan yang meliputi Kecamatan Ratatotok, Belang dan Pusomaen, juga terdapat di sekitar daerah Rasi, Tosuraya, Wawali, Pasan di Kecamatan Ratahan, Molompar dan Tombatu di Kecamatan Tombatu. Lereng antara $0-2 \%$ juga terdapat disekitar Ranoketang Atas, Lobu Kecamatan Touluaan dan Silian di Kecamatan Silian Raya.

Penggunaan lahan di Kabupaten Minahasa Tenggara secara umum terdiri atas 13 kelas seperti terlihat pada Tabel $1 \mathrm{di}$ berikut ini.

Tabel 1. Penggunaan lahan di Kabupaten Minahasa Tenggara

\begin{tabular}{|l|l|l|l|l|}
\hline \multirow{2}{*}{ No } & Penutup/ & Luas & \multicolumn{2}{l|}{} \\
\cline { 3 - 5 } & Penggunaan Lahan & Km2 & Hektar & Persen \\
\hline 1 & Hutan & 107,04 & 10.704 & 14,64 \\
\hline 2 & Kebun Campur & 368,34 & 36.834 & 50,38 \\
\hline 3 & Lahan Terbuka & 49,65 & 4.965 & 6,79 \\
\hline 4 & Mangrove & 5,31 & 531 & 0,73 \\
\hline 5 & Perkebunan Cengkeh & 14,92 & 1.492 & 2,04 \\
\hline 6 & Perkebunan Kelapa & 56,22 & 5.622 & 7,69 \\
\hline 7 & Permukiman & 12,61 & 1.261 & 1,72 \\
\hline 8 & Rawa & 0,63 & 63 & 0,09 \\
\hline 9 & Sawah & 24,49 & 2.449 & 3,35 \\
\hline 10 & Semak Belukar & 36,13 & 3.613 & 4,94 \\
\hline 11 & Tambak & 0,41 & 41 & 0,06 \\
\hline 12 & Tegalan/Ladang & 53,02 & 5.302 & 7,25 \\
\hline 13 & Tubuh Air & 2,43 & 243 & 0,33 \\
\hline Jumlah Total & $\mathbf{7 3 1 , 2 1}$ & $\mathbf{7 3 . 1 2 1}$ & $\mathbf{1 0 0 , 0 0}$ \\
\hline
\end{tabular}

Sumber : Hasil analisis Lembaga Penerbangan dan Antariksa Nasional (LAPAN) tahun 2012 
Dari Tabel terlihat bahwa penggunaan lahan terbesar adalah pada kebun campur sehingga perekonomian masyarakat di Minahasa Tenggara umumnya terfokus pada pertanian seperti kopra dan cengkih, dan sektor perikanan dan pariwisata di wilayah Kecamatan Ratatotok. Sebagian wilayah Minahasa Tenggara masih berupa hutan dengan luas sekitar 10,704 ha yang ditumbuhi berbagai tanaman seperti kelapa dan aren. Tanaman aren di Sulawesi Utara pada umumnya masih merupakan tanaman liar atau tanaman hutan dan hanya sebagian kecil yang telah ditanam pada daerah aliran sungai atau jurang. Aren dapat tumbuh pada lahan marginal di lereng gunung atau berbukit-bukit bersama tanaman lain sehingga di beberapa wilayah Sulawesi Utara, khususnya di Kabupaten Minahasa Tenggara pohon aren banyak dimanfaatkan oleh rakyat yang berpenghasilan rendah.

Luas lahan aren di Kabupaten Minahasa Tenggara mencapai 867,95 ha dengan produksi aren mencapai 166 ton pada tahun 2013 (BPS, 2013). Diperkirakan dalam 1 hektar terdapat 300-400 pohon aren, dimana jumlah tanaman aren yang produktif antara 100-150 pohon per ha sehingga diperkirakan jumlah nira yang dihasilkan per pohon rata-rata 25 liter/hari.

Mayang pohon aren menghasilkan cairan putih yang disebut dengan nira atau masyarakat lokal menyebutnya 'saguer'. Di hampir semua wilayah Kabupaten Minahasa Tenggara khususnya di Kecamatan Ratahan, nira aren atau saguer hanya dimanfaatkan sebagai bahan baku pengolahan gula aren dan pengolahan minuman beralkohol yang oleh masyarakat Sulawesi Utara dikenal dengan nama 'cap tikus' atau difermentasi menjadi cuka saguer.

Cap tikus adalah jenis cairan berkadar alkohol rata-rata 40 persen yang dihasilkan melalui penyulingan atau destilasi saguer dengan menggunakan penyulingan sederhana dan masih berupa home industry. Tinggi rendahnya kadar alkohol pada cap tikus tergantung pada kualitas penyulingan. Semakin bagus sistem penyulingannya, semakin tinggi pula kadar alkohol yang dihasilkan. Minuman ini telah akrab dengan masyarakat dan menjadi minuman khas daerah Sulawesi Utara bahkan telah menjadi sumber mata pencaharian bagi para petani aren di beberapa kabupaten di Sulawesi Utara khususnya di Kabupaten Minahasa Tenggara.

Nira aren oleh penduduk lokal selain dimanfaatkan sebagai bahan baku pengolahan cap tikus juga banyak dimanfaatkan sebagai bahan baku pengolahan gula merah atau gula aren. Di Kecamatan Ratahan pada umumnya pengrajin gula aren mengolah nira aren menjadi gula merah atau gula aren dalam bentuk mangkuk seperti yang banyak beredar di pasaran saat ini baik di swalayan ataupun pasar-pasar tradisional dan dipasarkan dengan harga $\mathrm{Rp} 7.500$ per batok ditingkat petani gula aren, tetapi masyarakat umumnya lebih suka mengolah nira 
aren menjadi cap tikus karena oleh masyarakat cap tikus sudah merupakan usaha home industry turun temurun dan dianggap lebih memiliki nilai ekonomis lebih tinggi daripada gula aren.

Awalnya minuman ini digunakan sebagai minuman penghangat badan oleh para petani tetapi lama kelamaan fungsi dari minuman ini telah bergeser menjadi minuman yang dapat menimbulkan kerawanan sosial. Minuman ini banyak dikonsumsi oleh masyarakat Sulawesi Utara baik orang tua maupun anak-anak remaja sehingga bisa menimbulkan potensi kriminal dan kecelakaan lalu-lintas bahkan bisa menimbulkan korban jiwa. Permasalahan dan kerawanan sosial banyak ditimbulkan akibat konsumsi minuman ini secara berlebihan sehingga peredaran minuman ini dihalangi oleh aparat keamanan, tetapi hal ini justru menimbulkan masalah baru bagi para petani yang hanya mengantungkan hidupnya dari produksi minuman ini.

Kecap merupakan ekstrak dari hasil fermentasi kedelai yang dicampurkan dengan bahan-bahan seperti gula kelapa dengan tekstur kental, berwarna coklat kehitaman, dan digunakan untuk meningkatkan cita rasa makanan (Suprapti, 2005). Saat ini hampir semua industri pengolahan kecap di Indonesia menggunakan gula kelapa sebagai bahan baku utama dalam pembuatan kecap manis. Nira kelapa disadap pada saat kelapa masih berumur muda sehingga kelapa yang telah disadap niranya tidak akan berbuah lagi padahal di Sulawesi Utara umumnya dan di Kabupaten Minahasa Tenggara khusunya orientasi dari tanaman kelapa adalah kopra sehingga tidak mungkin menggunakan nira kelapa sebagai bahan baku pembuatan kecap manis. Alternatif pengolahan kecap yang bisa dilakukan adalah pengolahan kecap berbahan baku nira aren.

\section{Permasalahan Mitra}

Preferensi minat kelompok tani aren untuk mengolah nira aren menjadi gula aren dan lebih memilih pengolahan minuman cap tikus serta keterbatasan ilmu pengetahuan dan teknologi menyebabkan petani aren hanya memanfaatkan nira aren sebagai bahan baku pengolahan minuman cap tikus dan gula aren, padahal gula aren dapat dimanfaatkan lanjut sebagai bahan baku utama dalam pengolahan kecap dengan memanfaatkan teknologi fermentasi kedelai.

Nilai ekonomis cap tikus yang lebih baik dibandingkan nilai ekonomis gula aren menambah preferensi petani aren lebih memilih mengolah cap tikus dibandingkan mengolah gula aren padahal peredaran cap tikus banyak menimbulkan masalah sosial dimasyarakat sehingga di wilayah Sulawesi Utara saat ini banyak beredar himbauan dari Kapolda Sulawesi Utara untuk "Brenti Jo Bagate" yang artinya berhenti untuk mengkonsumsi minuman keras diantaranya cap tikus. 


\section{Solusi dan Target Luaran}

Mencermati berbagai kondisi dan permasalahan yang ada di Kabupaten Minahasa Tenggara maka perlu adanya transfer ilmu pengetahuan dan teknologi bagi para petani aren yang ada di Kecamatan Ratahan tentang alternatif pemanfaatan nira aren. Salah satu alternatif ilmu pengetahuan dan teknologi yang bisa ditawarkan bagi para petani aren adalah teknologi pengolahan kecap berbahan baku gula aren dengan memanfaatkan teknologi fermentasi kedelai sehingga diharapkan nira aren bisa memiliki nilai ekonomis yang lebih baik bila dibandingkan hanya dimanfaatkan dalam pengolahan gula aren dan cap tikus. Produk olahan kecap dengan nilai ekonomis yang lebih baik diharapkan mendorong petani lebih memilih mengolah nira aren menjadi kecap dibandingkan menghasilkan cap tikus sehingga dengan beriringnya waktu peredaran cap tikus dimasyarakat semakin berkurang dan masalah sosial yang timbulkan juga semakin teratasi.

\section{METODE PELAKSANAAN}

\section{Metode Kerja}

Memahami situasi serta kondisi masyarakat petani aren yang ada di Kabupaten Minahasa Tenggara maka diperlukan adanya alih teknologi, sehingga guna keberhasilan kegiatan IbM ini maka metode yang digunakan adalah metode kaji tindak, yaitu suatu metode berupa pelatihan dan penyuluhan bagi para petani aren yang tergabung dalam kelompok tani dengan memberikan contoh secara langsung penerapan teknologi serta melibatkan para kelompok tani aren dalam kegiatan pengabdian ini yang dimulai dari pendampingan proses fermentasi kedelai sebagai bahan baku pembuatan kecap, pendampingan pembuatan gula aren hingga pendampingan dalam pengolahan kecap sehingga para petani bisa memahami metode dan proses-proses pengolahan kecap berbahan baku nira aren.

\section{Rencana Kegiatan}

Kegiatan pengabdian bagi Kelompok Tani Tousuraya Kecamatan Ratahan ini dibagi menjadi 5 tahapan utama, yaitu:

1. Penyiapan peralatan dan bahan;

2. Penyiapan instalasi untuk proses fermentasi kedelai;

3. Penyuluhan dan pelatihan proses fermentasi kedelai bagi para petani aren;

4. Penyuluhan dan pelatihan proses pembuatan kecap berbahan baku gula aren; dan

5. Evaluasi kegiatan.

Dalam setiap langkah operasional atau pelaksanaan kegiatan, tim pelaksana akan terus mendampingi kelompok petani aren) untuk tetap dapat melakukan pendampingan, pengawasan, memberikan petunjuk teknis atau pengarahan sesuai tahapan kegiatan dimulai dari pendampingan pembuatan gula aren, proses fermentasi kedelai 
hingga pengolahan kecap berbahan baku gula aren.

Evaluasi awal ditujukan untuk mengetahui kesiapan mental atas program yang akan dilaksanakan, mengetahui potensi sumber daya yang berkaitan dengan kebutuhan kegiatan serta rencana kegiatan yang akan dilaksanakan. Evaluasi/pemantauan kegiatan berjalan dilakukan untuk mengetahui tingkat pengetahuan dan ketrampilan aplikasi teknologi, juga pengamatan mencakup aspek kegiatan fisik meliputi penyiapan bahan gula aren, proses fermentasi dan aplikasi pengolahan gula aren menjadi kecap.

Setelah program berakhir tetap dilakukan pemantauan kegiatan secara langsung proses pembuatan kecap berbahan baku gula aren pada tempat kegiatan, mencari informasi tanggapan masyarakat luas, pemerintah setempat dan instansi terkait.

\section{HASIL DAN PEMBAHASAN}

Program Pengabdian Kepada Masyarakat di Desa Tousuraya Kecamatan Ratahan Timur, Kabupaten Minahasa Tenggara diawali dengan pendampingan dalam pemberian contoh proses fermentasi kedelai sebagai bahan baku utama dalam proses pembuatan kecap. Fermentasi kedelai untuk menghasilkan air kacang atau moromi yang merupakan bahan baku utama dalam pembuatan kecap berbahan baku gula aren. Air kacang yang layak digunakan sebagai bahan baku merupakan hasil fermentasi selama lebih kurang 4 bulan, fermentasi yang sempurna akan menghasilkan rasa dan aroma yang baik. Selama proses fermentasi dilakukan penambahan garam. Larutan garam berfungsi sebagai pengawet dan penyeleksi mikroba yang tumbuh sehingga memungkinkan pertumbuhan khamir dan bakteri asam laktat yang merupakan pembentuk aroma dan flavor pada kecap (Astawan 2009). Menurut Fukushima (2003), larutan garam untuk fermentasi moromi sekitar 20 - 23\%. Konsentrasi garam yang terlalu tinggi dapat menghambat proses fermentasi, sedangkan konsentrasi yang terlalu rendah dapat menyebabkan terjadinya kerusakan (Huang dan Teng 2004).

Mikroorganisme yang berperan dalam fermentasi moromi adalah Pediococcus halophilus (bakteri asam laktat) yang tumbuh dan memproduksi asam laktat pada awal fermentasi dan menurunkan $\mathrm{pH}$ moromi dari 6.5-7.0 menjadi kurang dari 5, Zygosaccharomyces rouxii atau Saccharomyces rouxii (khamir osmofilik) yang tumbuh pada pertengahan fermentasi dan menurunkan pH serta melakukan fermentasi alkoholik; dan Torulopsis sp. atau Candida sp. (khamir halofilik) yang tumbuh pada akhir fermentasi dan memproduksi beberapa komponen fenolik dan menambah aroma pada kecap (Fukushima 2003).

Selama proses fermentasi moromi, pati dipecah menjadi alkohol dan asam laktat, 
sedangkan protein dipecah menjadi peptida dan asam amino (Sun et al. 2010). Fermentasi moromi juga akan menghasilkan produk akhir berupa asam laktat, asam suksinat, asam asetat, piroglutamat, dan yang utama adalah asam glutamat (penimbul rasa sedap) (Astawan 2009). Selain itu, selama fermentasi moromi, warna larutan kecap akan berubah yang disebabkan oleh warna yang terbentuk sebagai hasil reaksi enzimatis browning antara gula pereduksi dengan gugus amino dari protein (Astawan dan Wahyuni 1991). Proses fermentasi moromi dapat dilihat pada Gambar 1 berikut ini.

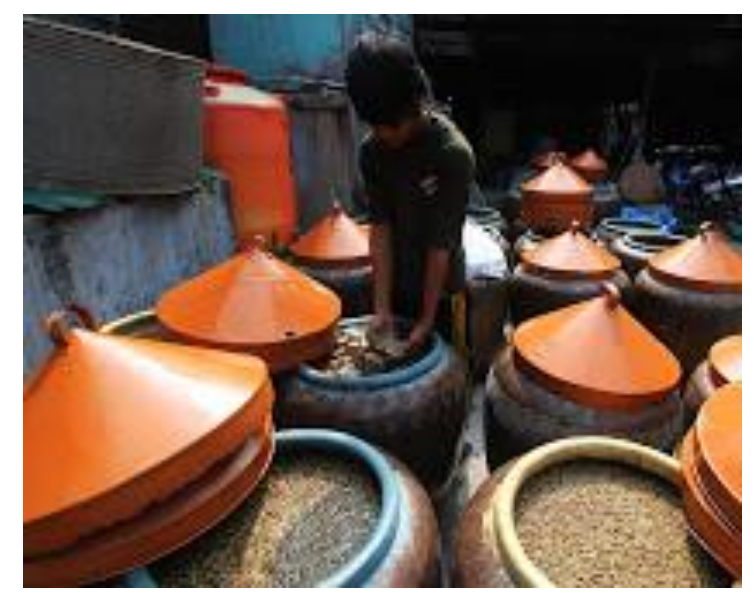

Gambar 1. Proses fermentasi kedelai.

Setelah proses fermentasi moromi selesai, moromi ditambahkan air supaya volume kecap yang dihasilkan menjadi banyak. Proses selanjutnya adalah penyaringan moromi sebagai bahan baku pembuatan kecap seperti terlihat pada Gambar 2. berikut ini.

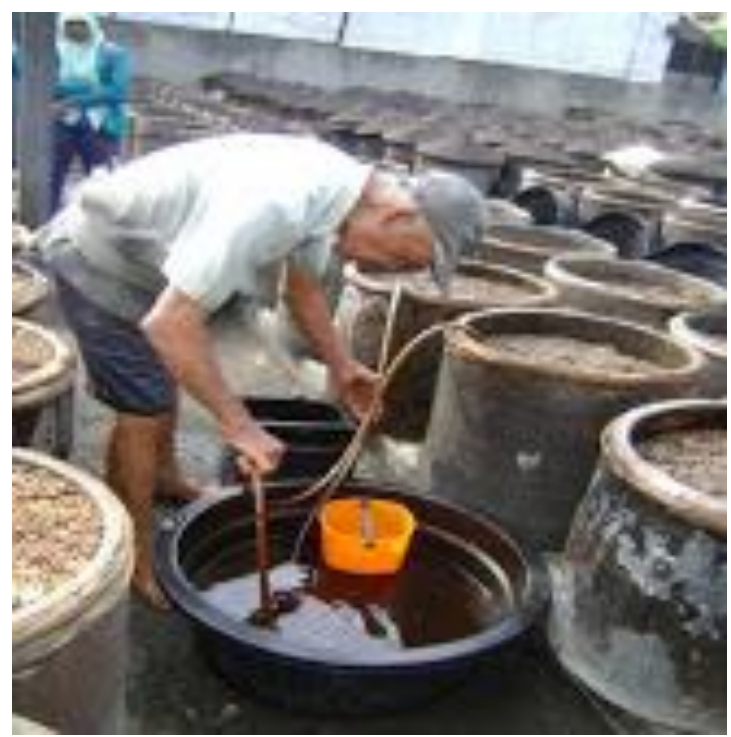

Gambar 2. Proses penyaringan moromi.

Kegiatan selanjutnya adalah proses pengolahan moromi menjadi kecap. Dalam proses pembuatan kecap, moromi hasil fermentasi kedelai dimasak bersama dengan gula aren dengan penambahan beberapa bumbu tertentu seperti adas dan pekak untuk menambah citarasa kecap. Setelah proses penambahan gula aren dan bumbu ke dalam moromi, dilakukan proses pemasakan hingga mendidih. Proses pemasakan merupakan tahap penting dalam menentukan warna dan flavor kecap. Hal ini dikarenakan selama proses pemasakan terjadi dua reaksi penting, yaitu reaksi Maillard dan reaksi karamelisasi (Amalia 2008). Proses pemasakan bertujuan untuk mendapatkan kecap yang berwarna coklat tua, bercita rasa spesifik, serta memperoleh kekentalan tertentu (Astawan 2009). Proses pemasakan berpengaruh terhadap kualitas warna, rasa, dan tekstur. Menurut Asryani (2007), jika pemasakan terlalu lama, kecap 
akan menjadi terlalu kental dan kemungkinan menjadi karamel dan rasanya menjadi pahit. Selama proses pemasakan dilakukan pengadukan terus-menerus untuk mencegah terjadinya pemanasan yang terlalu tinggi pada bagian bawah adonan seperti terlihat pada Gambar 3 di bawah ini.

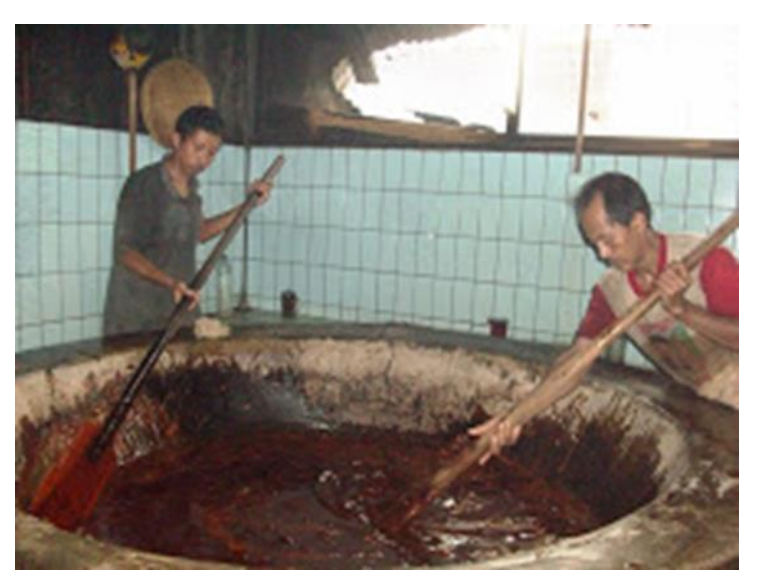

Gambar 3. Proses pembuatan kecap.

Diseminasi pengolahan kecap yang dimulai dari proses fermentasi kedelai menjadi moromi dan pengolahan kecap berbahan baku gula aren disajikan dalam kegiatan Pengabdian Kepada Masyarakat bagi petani aren di Desa Tousuraya, Kecamatan Ratahan Timur. Beberapa kegiatan diseminasi dapat dilihat pada Gambar 4.

Kegiatan dengan sasaran petani aren dilakukan dengan tujuan untuk para petani aren memperoleh informasi hilirisasi produk aren menjadi berbagai olahan lain seperti kecap, karena selama ini aren oleh petani aren hanya diolah menjadi gula aren dan cap tikus. Dengan adanya kegiatan ini diharapkan petani aren selain memperoleh pengetahuan tentang pengolahan kecap, di- harapkan ke depannya terbentuk kelompok tani aren yang dapat menghasilkan kecap berbahan baku gula aren sehingga dapat meningkatkan perekonomian masyarakat petani aren.
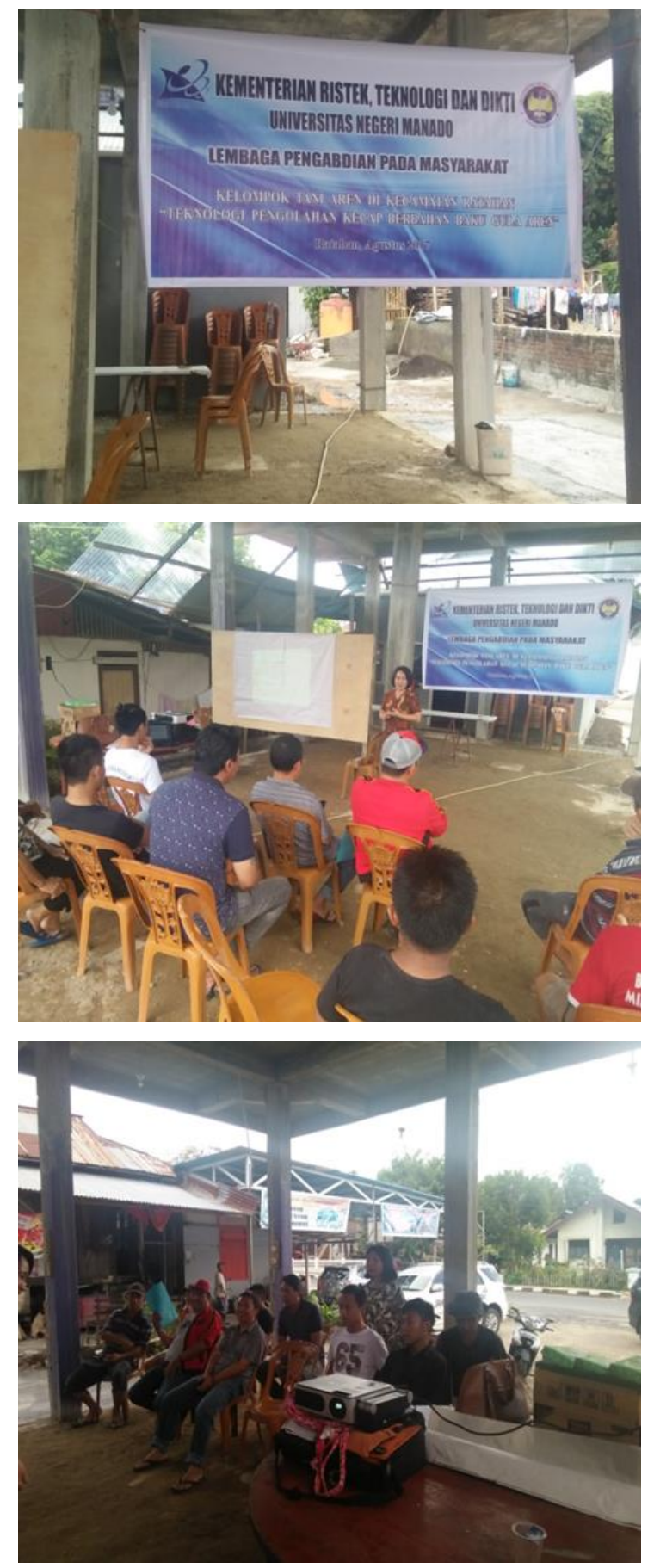

Gambar 4. Diseminasi pembuatan kecap berbahan baku gula aren. 


\section{KESIMPULAN}

Kegiatan Pengabdian bagi petani aren di Desa Tousuraya, Kecamatan Ratahan Timur memberikan manfaat yaitu perolehan informasi mengenai hilirisasi aren menjadi berbagai olahan selain gula aren dan cap tikus yaitu pengolahan kecap berbahan baku gula aren.

\section{KEPUSTAKAAN}

Anonymous. 2012. Hasil analisis Lembaga Penerbangan dan Antariksa Nasional (LAPAN) tahun 2012. LAPAN.

Asryani DM. 2007. Eksperimen Pembuatan Kecap Manis dari Biji Turi dengan Bahan Ekstrak Buah Nanas. Skripsi. Universitas Negeri Semarang. Semarang.

Astawan M. 2009. Sehat dengan Hidangan Kacang dan Biji-bijian. Penebar Swadaya. Jakarta.
Astawan M, Wahyuni M. 1991. Teknologi Pengolahan Pangan Nabati Tepat Guna. Akademika Pressindo. Jakarta.

BPS. 2013. Sulut Dalam Angka. Badan Pusat Statistik Sulawesi Utara.

Fukushima. 2003. Fermented Soy Sauce Production. Di dalam : Steinkraus KH (ed.). Industrialization of Indigenous Fermented Foods 2nd Ed. Marcel Dekker, Inc. New York.

Huang T, Teng D. 2004. Soy Sauce : Manufacturing and Biochemical Changes. Di dalam : Hui YH, Lisbeth MG, Ase SH, Jytee J, Wai-Kit N, Peggy SS, Fidel $\mathrm{T}$ (eds.). Handbook of Food and Beverage Fermentation Technology. Marcel Dekker, Inc. New York.

Su Y, Wang D, Fan WL, Mu XQ, Chen J. 2010. Traditional Chinese Biotechnology. Di dalam : Shu YS, Wen GJ, Yu PZ. Profile of volatile compounds in 12 chinese soy sauces produces by a high-salt-diluted state fermentation. Journal of The Institute of Brewing 116 (3): 316-328. 
Jurnal ABDIMAS, Vol. 11, No. 2, Agustus 2018

ISSN: 1979-0953 | e-ISSN: 2598-6066 